\title{
Bacterial cellulose nanofiber-based films incorporating gelatin hydrolysate from tilapia skin: production, characterization and cytotoxicity assessment
}

\author{
Helder Levi Silva Lima • Catarina Gonçalves • Miguel Ângelo Cerqueira • \\ Elígenes Sampaio do Nascimento • Miguel F. Gama • Morsyleide F. Rosa • \\ Maria de Fátima Borges • Lorenzo Miguel Pastrana • Ana Iraidy Santa Brígida $(\mathbb{C}$
}

Received: 8 April 2018/Accepted: 8 August 2018/Published online: 20 August 2018

(C) Springer Nature B.V. 2018

\begin{abstract}
In this work, films based on bacterial cellulose nanofibers (BCNFs) incorporating gelatin hydrolysate $(\mathrm{GH})$ from tilapia skin were produced. The effect of plasticizer (sorbitol or glycerol) and GH incorporation was evaluated on the physical-chemical and optical properties of films. BCNFs were produced using bacterial cellulose obtained from Hestrin and Schramm (HS) medium (BCNF-HS) or cashew apple juice (BCNF-CM), which was studied as an alternative to HS. Films with sorbitol showed the best properties and were selected for further characterization, using $40 \%$ (w/w) of BCNF-HS, $40 \%$ (w/w) of GH and $20 \%$ (w/w) of sorbitol (BCNF-HS-S-GH films). These films
\end{abstract}

exhibited an antioxidant activity of $7.8 \mu$ mols Trolox $\mathrm{Eq} / \mathrm{g}$ film, a water vapor permeability (WVP) of 1.6 g.mm $/ \mathrm{kPa} . h . \mathrm{m}^{2}$ and an Young's modulus of $0.57 \mathrm{GPa}$. Films produced with BCNFs obtained from cashew apple juice revealed enhanced tensile strength, elongation at break, and thermal stability. Caco-2 cells' viability after incubation with BCNF-based films incorporating $\mathrm{GH}$ was evaluated and showed non-cytotoxicity, reinforcing the safety of the developed materials and their potential use in food applications.

\footnotetext{
H. L. S. Lima · E. S. do Nascimento

Department of Chemical Engineering, Federal University

of Ceará (UFC), Fortaleza, CE, Brazil

C. Gonçalves · M. Â. Cerqueira · L. M. Pastrana International Iberian Nanotechnology Laboratory, Braga, Portugal
}

M. F. Gama

CEB - Centre of Biological Engineering, University of Minho, Braga, Portugal

\author{
M. F. Rosa - Maria de FátimaBorges · A. \\ I. S. Brígida ( $\square)$ \\ Embrapa Agroindústria Tropical, Fortaleza, CE, Brazil \\ e-mail: ana.iraidy@embrapa.br
A. I. S. Brígida
Embrapa Agroindústria de Alimentos, Rio De Janeiro, RJ, Brazil




\section{Graphical abstract}

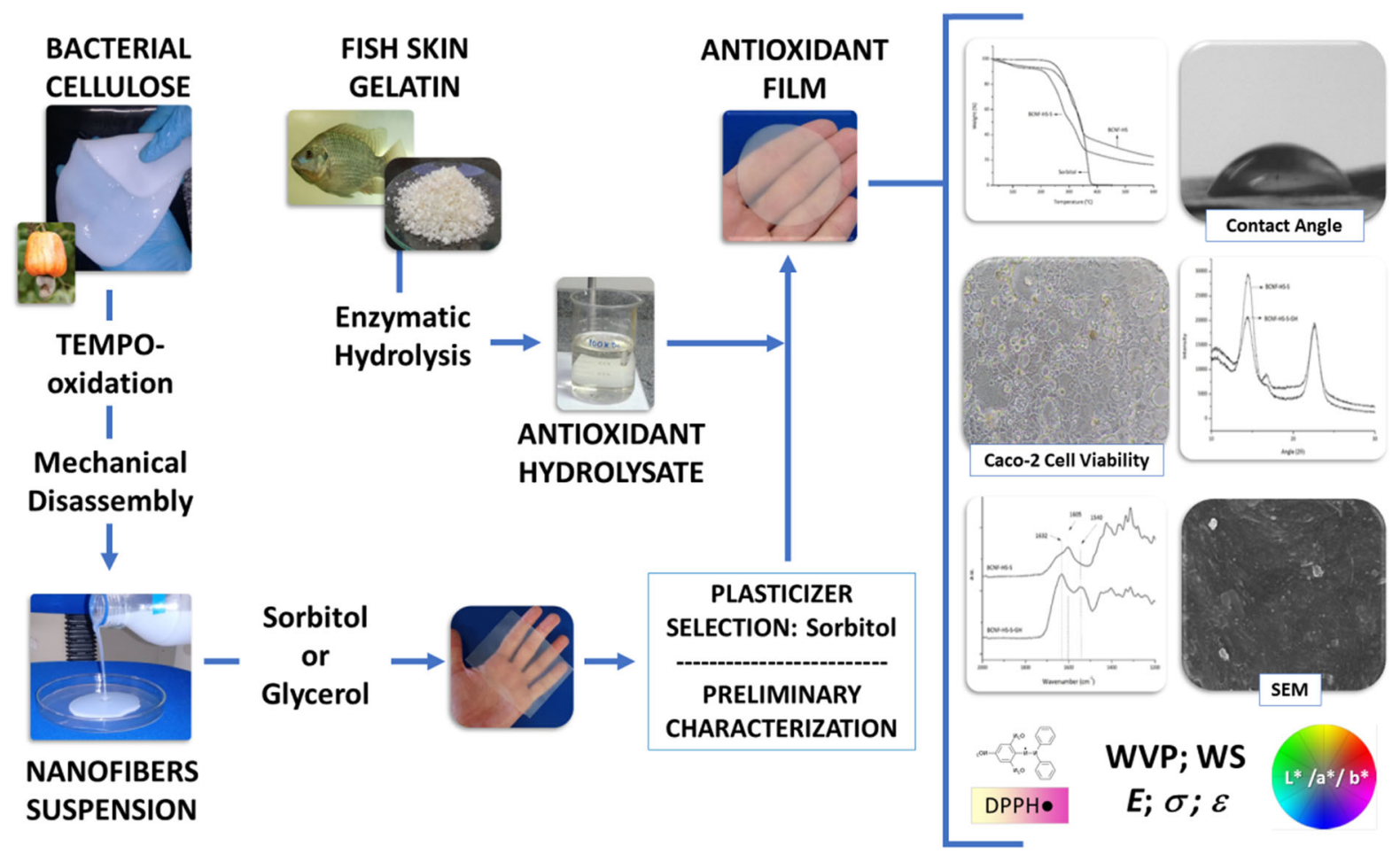

Keywords Biocomposite - Antioxidant .

Plasticizer - Bioactive film - Cashew apple juice .

Gelatin hydrolysate

\section{Introduction}

Bioactive edible films and coatings have been reported by many authors (Padrão et al. 2016; Salgado et al. 2015) to preserve and improve food quality and safety. Their use can increase the food shelf life through the decrease of microbiological growth and oxidation phenomena by controlling the release of bioactive agents on the food surface. In this context, antioxidants, antimicrobials, nutrients, nutraceuticals, flavours and dyes can be added to edible films and coatings, bringing different and additional functionalities (Coma et al. 2008; Perez et al. 2012). Natural polymers and bioactive compounds are the preferential choice for these applications, addressing the consumers demand for natural and safe food products complying with the regulator requests, and also meeting environmental issues related with disposal of non-biodegradable and non-renewable packaging (Atarés and Chiralt 2016; Bauer et al. 2001). It is nevertheless important to evaluate the toxicity of the produced films, since the production process may convert some components into non-safe substances (Montero et al. 2017).

Proteins from marine source have been explored to produce hydrolysates with antioxidant activity (Sila and Bougatef 2016). Tilapia (Oreochromis niloticus) is one of the several fish species studied for this purpose (Sampaio et al. 2017). These bioactive peptides, obtained by chemical or enzymatic hydrolysis of proteins, have been studied to develop bioactive films exploring their functional properties, such as antioxidant activity (Chi et al. 2015; Genskowsky et al. 2015; Martínez-Alvarez et al. 2015; Perez et al. 2012; Sun et al. 2015; Zhang 2016). Despite this, only few studies evaluated the potential of using antioxidant peptides in bacterial cellulose films for food applications (Han and Aristippos 2005; Lin et al. 2015a, b; Nguyen et al. 2008; Samaranayaka et al. 2011).

Bacterial cellulose (BC) is an extracellular polysaccharide excreted by bacteria from the genre 
Komagataeibacter (previously named Gluconacetobacter) (Yamada et al. 2012), chemically identical to the vegetal cellulose but without the presence of lignin or hemicelluloses. BC is a promising polysaccharide for application in the food industry due to its high purity, food grade status, hydrophilicity, high sorption capacity of liquids and flexibility to be molded, colored and flavored. Moreover, BC can also be used as food additive to increase thermal stability, as texturizer and fat replaces (Shi et al. 2014; Ullah et al. 2016). Indeed, BC is a traditional dessert in Asia, particularly in the Philippines, known as 'Nata de Coco', mainly produced from coconut water and pineapple juice by simple static fermentation being independent of seasonal factors (Chawla et al. 2009).

The Hestrin \& Schramm (HS) culture medium is usually used for BC production (Hestrin and Schramm 1954), although other synthetic media have been developed (Mohammadkazemi et al. 2015). Several studies have evaluated low-cost media for BC production, such as fruit juices, syrups, molasses, coconut water, glycerol, waste products and others (Jahan et al. 2017; Jozala et al. 2016; Chawla 2009; Duarte et al. 2015; Nascimento et al. 2016; Lima et al. 2017). The cashew crop peduncle (Anacardium occidentale, L.), a waste from cashew nuts processing, release citric acid and sugar when squeezed and despite the efforts, only $10 \%$ of the total waste produced is re-used in food manufacturing (Silveira et al. 2012). One of the possibilities for the valorization is to use this waste as an alternative culture medium for BC production (Duarte et al. 2015).

Currently, natural nanofibers are widely studied to produce high-performance biodegradable materials, such as reinforced packaging, composites, electronic paper, optical membranes, barrier films, flame-resistant materials, and other high-tech materials (Isogai et al. 2011; Kargarzh et al. 2017). One of the sources of natural nanofibers is cellulose, in which the chemical treatment and/or mechanical deconstruction can be applied, to obtain cellulose fibers in nanoscale. Mechanical treatments include homogenization, high-pressure microfluidization, mechanical deconstruction in a blender, and ultrasonication (Coelho et al. 2018; Lavoine et al. 2012). Chemical treatments, such as N-oxyl-2,2,6,6-tetramethylpiperidine (TEMPO)-mediated oxidation, carboxymethylation, acetylation, and/or enzymatic treatment usually precedes mechanical deconstruction. TEMPO-mediated oxidation has been used to obtain more uniform cellulose fibers after mechanical treatment, facilitating the separation of aggregated micro/nanostructures and enhancing stability. TEMPO-mediated oxidation provides advantages when compared to other chemical treatments, such as maintenance of the crystallinity and morphology of the fibers, fast reaction, mild process conditions (temperature and pressure), chemical selectivity and non-reactivity/sensibility to light, air or moisture (Isogai et al. 2011). Although many processes to obtain vegetal cellulose nanofibers had been widely studied, few report the production of nanofibers based on bacterial cellulose (BCNF) and their use in obtaining films (Saito et al. 2006; Tsalagkas et al. 2016).

In this context, this work aimed to produce and characterize BCNF based-films incorporating tilapia skin gelatin hydrolysate (GH). The effect of plasticizers (sorbitol or glycerol) and GH on properties of BCNF-based films was evaluated. Also, the influence of the BCNF source on the characteristics of BCNFbased films obtained was investigated by substituting BCNFs derived from fermentation in synthetic medium for BCNFs from an alternative medium (cashew apple juice). Selected films were characterized by water vapor permeability, water solubility, mechanical properties, thermal properties, antioxidant activity, including the cytotoxicity evaluation using a human intestinal epithelial cell line.

\section{Materials and methods}

\section{Materials}

Bacteriological agar, casein peptone, and yeast extract powder were purchased from Difco ${ }^{\mathrm{TM}}$ (Becton, Dickinson and Company, Sparks, MD, USA). D-Mannitol, citric acid hydrate, anhydrous D (+) glucose, sodium dihydrogen phosphate anhydrous, hydrogen peroxide, hydrochloric acid, sodium hydroxide, 2,2,6,6-Tetramethyl-1-piperidinyloxy (TEMPO), 6-hydroxy-2,5,7,8tetramethylchroman-2-carboxylic acid (TROLOX), sodium bromide, potassium bromide, sodium hypochlorite, magnesium nitrate, glycerol, and sorbitol were purchased from Sigma-Aldrich (Brazil). Resazurin, 2,2-Diphenyl-1-picrylhydrazyl (DPPH) and sodium pyruvate were purchased from SigmaAldrich (St Louis, MO, USA). Alcalase $2.4 \mathrm{~L}$ was a 
donation from Novozymes ${ }^{\circledR}$ (Bagsvaerd, Denmark). The cashew apple juice was collected in the Embrapa Tropical Agroindustry experimental field in Pacajus city (Ceará, Brazil). MEM (Minimum Essential Medium) was purchased from Thermo Scientific (Stafford, United Kingdom). Penicillin/streptomycin, fetal bovine serum (FBS) and non-essential aminoacids were purchased from Millipore (Darmstadt, Germany).

Preparation of bacterial cellulose nanofibers

Komagataeibacter xylinus ATCC 53582 strain, kept at $-18{ }^{\circ} \mathrm{C}$ in HS medium with glycerol $20 \%$ (w/v), was activated in mannitol broth $(5.0 \mathrm{~g} / \mathrm{L}$ of yeast extract, $3.0 \mathrm{~g} / \mathrm{L}$ of peptone and $2.5 \mathrm{~g} / \mathrm{L}$ of D-mannitol) and statically cultured at $30{ }^{\circ} \mathrm{C}$ for 2 days. The culture was propagated by inoculation of $3 \%(\mathrm{v} / \mathrm{v})$ from mannitol broth to HS medium (Hestrin and Schramm 1954) at $30{ }^{\circ} \mathrm{C}$ for $24 \mathrm{~h}$ and propagated for two more days to create the inoculum. BC membranes used in this study were obtained by bacteria cultivation in HS medium at pH 6.0 or cashew apple juice medium (CM) with $100 \mathrm{~g} / \mathrm{L}$ of total reducing sugar at pH 6.0. Both culture media were autoclaved at $121{ }^{\circ} \mathrm{C}$ for $15 \mathrm{~min}$, before inoculation. The $\mathrm{BC}$ was produced in glass bowl $(25 \times 27 \mathrm{~cm})$ containing $500 \mathrm{~mL}$ of medium with $3 \%$ of inoculum (v/v), incubated at $30{ }^{\circ} \mathrm{C}$ under static conditions for 10 days. After fermentation, BC membranes were harvested and purified by alkali treatment prior to dry weight determination. For this purpose, impure films were washed in hot water $\left(90{ }^{\circ} \mathrm{C}\right)$, following immersion into an alkaline solution (1 M $\mathrm{NaOH}+1 \% \mathrm{H}_{2} \mathrm{O}_{2}$ v/v) at $80 \mathrm{C}$ for $1 \mathrm{~h}$. Finally, BC membranes were rinsed with distilled water until $\mathrm{pH}$ 7.0. $\mathrm{BC}$ membranes from $\mathrm{HS}$ medium or $\mathrm{CM}$ are further referred as BC-HS and BC-CM, respectively.

To produce oxidized bacterial cellulose, BC-HS or BC-CM membranes were dried (at $50{ }^{\circ} \mathrm{C}$ ), triturated and oxidized by TEMPO following a methodology developed by Saito et al. (2007), with few modifications. Dry films were suspended in distilled water (100 mL per gram of film) containing TEMPO and $\mathrm{KBr}(0.016 \mathrm{~g}$ and $0.1 \mathrm{~g}$ per gram of film, respectively). The oxidation was initiated by addition of $\mathrm{NaClO} 11 \%$ solution ( $\mathrm{NaClO} 5.0 \mathrm{mmol} / \mathrm{g}$ on a dry BC basis) to the suspension, at $25{ }^{\circ} \mathrm{C}$, under stirring (500 rpm). After $20 \mathrm{~min}$, the $\mathrm{pH}$ was adjusted to 10.0 by adding $0.5 \mathrm{M}$ $\mathrm{NaOH}$ solution, and the suspension was kept under magnetic stirring for further $2 \mathrm{~h}$. The suspension was then washed up to $\mathrm{pH}$ 7.0. BCNFs from BC-HS or BC$\mathrm{CM}$ media are further referred as BCNF-HS and BCNF-CM, respectively. After that, BCNFs (BCNFHS or BCNF-CM) were mechanically treated in high speed blender (VITAMIX ${ }^{\circledR} 5200$ Standard-Getting Started) at $25000 \mathrm{rpm}$ for $30 \mathrm{~min}$, in three cycles (10 min each). The nanometric scale of the BCNF suspension was confirmed by transmission electron microscopy (TEM) analysis (data not shown).

Production of gelatin hydrolysate (GH) from fish skin

Tilapia skins received from filet processing unit (Fortaleza, Brazil) were immediately frozen until processing. The procedure defined by Sampaio et al. (2017) was used for gelatin extraction. Total protein in the dry gelatin powder was determined by Kjeldahl method (Kjeldahl 1883) using a factor of 5.55 to convert nitrogen into protein content.

To produce gelatin hydrolysate $(\mathrm{GH})$, tilapia skin was dissolved in water $(10 \mathrm{~g} / \mathrm{L})$ and hydrolyzed enzymatically using Alcalase $2.4 \mathrm{~L}^{\circledR}$ (enzyme/substrate ratio of $5 \%$ ) under controlled temperature $\left(55^{\circ} \mathrm{C}\right)$ and $\mathrm{pH}(6.0)$ for $3 \mathrm{~h}$ under magnetic stirring (300 rpm). The solution $\mathrm{pH}$ was adjusted with $\mathrm{HCl}$ or $\mathrm{NaOH}$. The crude hydrolysate was heated at $80{ }^{\circ} \mathrm{C}$ for $10 \mathrm{~min}$ to stop the enzymatic reaction. After inactivation, the crude hydrolysate was concentrated to $90 \mathrm{~g} / \mathrm{L}$ using a rotavapor $\left(50{ }^{\circ} \mathrm{C}, 40 \mathrm{mbar}\right)$, filtered through $0.22 \mu \mathrm{m}$ membrane (Millex-hydrophilic PVDF, Brazil), and stored at $-18{ }^{\circ} \mathrm{C}$, before use. Total protein content in $\mathrm{GH}$ was $88.5 \%(\mathrm{w} / \mathrm{w})$ being $68.25 \%(\mathrm{w} / \mathrm{w})$ hydrolyzed gelatin $(<100 \mathrm{kDa})$ and $20.25 \%(\mathrm{w} / \mathrm{w})$ non-hydrolyzed gelatin $(>100 \mathrm{kDa})$.

To evaluate the peptide-sizes range obtained in the final hydrolysate, GH concentrated was filtered through a $10 \mathrm{kDa}$ membrane and then through a $3 \mathrm{kDa}$ membrane, using Amicon Ultra $4 \mathrm{~mL}$ centrifugal filters (Ultracel regenerated cellulose, Merck $\mathrm{KGaA}$, Germany). The protein content, in each filtrate, was quantified by spectrophotometry, as described by Anthis and Clore (2013), using GH as standard. The antioxidant capacity of the gelatin hydrolysate was evaluated using DPPH method (Yang et al. 2009). The concentration of hydrolysate necessary to decrease the initial activity of DPPH - by $50 \%\left(\mathrm{IC}_{50}\right)$ was $38.66 \mathrm{mg} /$ $\mathrm{mL}$. The $\%$ mass and antioxidant activity in each 
Table 1 Composition (\%,w/w) of BCNF-based films

\begin{tabular}{llll}
\hline Formulated films & \multicolumn{2}{l}{ Components $(\%, w / w)$} & Gelatin hydrolysate $(\mathrm{GH})$ \\
\cline { 2 - 4 } & BCNF & Plasticizer (sorbitol or glycerol) & 0 \\
\hline BCNF-HS & 100.0 & 0 & 0 \\
BCNF-HS-S or BCNF-HS-G & 66.7 & 33.3 & 40.0 \\
BCNF-HS-S-GH or BCNF-CM-S-GH & 40.0 & 20.0 & 0 \\
\hline
\end{tabular}

BCNF-HS-S (composed of BCNFs from HS medium and sorbitol), BCNF-HS-G (composed of BCNFs from HS medium and glycerol), BCNF-HS-S-GH (composed of BCNFs from HS medium, sorbitol and gelatin hydrolysate) or BCNF-CM-S-GH (composed of BCNFs from cashew juice medium, sorbitol and gelatin hydrolysate)

fraction was: $68.63 \%$ and $\mathrm{IC}_{50} 25.07 \mathrm{mg} / \mathrm{mL}$ for $<$ $10 \mathrm{kDa}$ fraction and $46.52 \%$ and $\mathrm{IC}_{50} 32.97 \mathrm{mg} / \mathrm{mL}$ for $<3 \mathrm{kDa}$ fraction, respectively.

Hydrolysate incorporation within BCNF-based films

To produce BCNF-based films incorporating gelatin hydrolysate, $400 \mathrm{~mL}$ of film-forming solution, composed by BCNF suspension (BCNF-HS or BCNF$\mathrm{CM})(1 \%, \mathrm{w} / \mathrm{v})$ and $\mathrm{GH}$ solution $(1 \%, \mathrm{w} / \mathrm{v})$, at 1:1 (v/v) ratio, was dried in a polyethylene tray $(20 \times 15 \mathrm{~cm})$ with polypropylene plastic sheet underneath the liquid, at $50{ }^{\circ} \mathrm{C}$ for $48 \mathrm{~h}$. For plasticizer application, $1 \mathrm{~g}$ of sorbitol or glycerol was previously dissolved in $200 \mathrm{~mL}$ of $1 \%(\mathrm{w} / \mathrm{v}) \mathrm{GH}$. Control films were produced dissolving sorbitol or glycerol in water instead of in $\mathrm{GH}$, and after being mixed with the BCNF suspension. The film-forming solutions were degassed before pouring the mixture onto the polyethylene tray. The GH amount used in the film-forming solution was previously selected in exploratory tests (data not shown) where the antioxidant activity was evaluated. The composition of the dry films is described in Table 1.

Characterization of BCNF-based films

\section{Mechanical properties}

Tensile tests (at least eight replicates) were conducted following ASTM D882-97 methodology (ASTM 1997) with few modifications. The films were cut $(12.6 \times 1.2 \mathrm{~cm})$ and stored in a desiccator with controlled humidity (with magnesium nitrate $50-55 \%$ ) for $48 \mathrm{~h}$. The measurements were performed in a Universal Testing Machine (EMIC DL3000), with $12.5 \mathrm{~mm} / \mathrm{min}$ draw speed, $50 \mathrm{kgf}$ load cell employed and $10 \mathrm{~cm}$ of initial gap.

\section{Thermogravimetric analysis (TGA)}

Thermogravimetric analysis of films was performed on a thermogravimetric analyzer (Shimadzu, TGA STA 6000), using $10 \mathrm{mg}$ of dried samples in the range of $0-600{ }^{\circ} \mathrm{C}$ under a nitrogen atmosphere $(40 \mathrm{~mL} /$ min) at $10{ }^{\circ} \mathrm{C} / \mathrm{min}$ of heating rate. Maximum degradation temperature $\left(\mathrm{T}_{\max }\right)$, initial degradation temperature $\left(\mathrm{T}_{\text {onset }}\right)$ and final degradation temperature $\left(\mathrm{T}_{\text {ofset }}\right)$ values were identified for the evaluation of thermal stability.

\section{Morphology}

The morphology of films was evaluated by Scanning Electron Microscopy (SEM). For SEM analysis, the films were mounted on stubs, coated with gold and observed in a MEV TESCAN Scanning Electron Microscope, under $15 \mathrm{kV}$ voltage acceleration.

\section{Water vapor permeability (WVP) and water solubility} (WS)

The water vapor permeability (WVP) of films was determined following E96-05 method with few modifications (ASTM 1989). Five circular samples (area of $22 \mathrm{~cm}^{2}$ ) were sealed as patches onto acrylic permeation cells containing $6 \mathrm{~mL}$ of distilled water. The cells were placed in a desiccator with steady flow of dried air and weighed on an analytical balance at different time points up to $24 \mathrm{~h}$. Eight measurements 
were performed in each circular sample and the average was considered.

The water solubility (WS) was determined following the methodology reported by Soni et al. (2016), with few modifications. The films $(2 \times 2 \mathrm{~cm})$ were dried $\left(103{ }^{\circ} \mathrm{C}, 24 \mathrm{~h}\right)$ and weighted. Each film was immersed in $50 \mathrm{~mL}$ of distilled water and magnetically stirred $(150 \mathrm{rpm})$ for $24 \mathrm{~h}$ at $25^{\circ} \mathrm{C}$. After that, the remaining film was filtered in paper (porosity $8 \mu \mathrm{m})$, dried $\left(103{ }^{\circ} \mathrm{C}, 24 \mathrm{~h}\right)$ and weighted. Results were express in percentage of mass loss.

\section{Contact angle}

The contact angle was measured in a face contact angle meter (OCA 20, Dataphysics, Germany) at $19^{\circ} \mathrm{C}$, by the sessile drop method (Albuquerque et al. 2017) using a syringe equipped with a needle with internal diameter of $0.713 \mathrm{~mm}$ (Hamilton, Switzerland). Contact angle measurements were performed $120 \mathrm{~s}$ after placing a drop $(3 \mu \mathrm{L})$ of ultrapure water on the film surface. Images were captured by CCD video camera (resolution of $752 \times 582$ pixels) and processed by C20 software. At least 12 measurements were performed for each sample to obtain an average value.

\section{Fourier-transform infrared (FTIR) spectroscopy}

FTIR spectra were recorded with a Bruker FT-IR VERTEX 80/80v (Boston, USA) in Attenuated Total Reflectance mode (ATR) with a platinum crystal accessory in the wavelength range: $4000-400 \mathrm{~cm}^{-1}$, using 16 scans at a resolution of $4 \mathrm{~cm}^{-1}$. Before analysis, an open beam background spectrum was recorded, as a blank.

\section{$X$-ray diffraction $(X R D)$}

$\mathrm{X}$-ray diffraction patterns of the films were analyzed between $2 \theta=10^{\circ}$ and $2 \theta=50^{\circ}$ with a step size $2 \theta=0.02^{\circ}$ and recorded $14 \mathrm{pts} / \mathrm{s}$ with a $\mathrm{Cu}$ source, $\mathrm{X}$-ray tube $(\lambda=1.54056 \AA)$ at $45 \mathrm{kV}$ and $40 \mathrm{~mA}$ in an $\mathrm{X}$-ray diffraction instrument (X'Pert ${ }^{3}$ Powder, PANalytical, Almelo, Netherlands). The crystallinity degree $\left(C_{D}\right)$ was calculated according to Segal et al. (1959).

\section{Transparency and color}

Transparency was determined according to Podshivalov et al. (2017), using a solid module of Varian spectrophotometer (Cary 50). Color of films was measured with a Colorimeter (Hunter Lab System, by a Chroma Meter CR-300-Konica Minolta Sensing Inc., Osaka, Japan) and results were expressed in $L^{*}$, $a^{*}, b^{*}$ parameters.

\section{Film thickness}

The films thickness was measured using a digital micrometer (Mitutoyo-QuantuMike IP65, Japan). Five measures were performed in each test film and the average was considered for Young's modulus $(E)$, tensile strength $(\sigma)$, and elongation at break $(\varepsilon)$ calculations.

\section{Antioxidant activity (AA)}

Antioxidant activity (AA) of films was determined using the DPPH method (Yang et al. 2009) adapted for films. Each film $(0.7 \times 0.7 \mathrm{~cm}$, corresponding to $9 \mathrm{mg}$ ) was immersed in $1.5 \mathrm{~mL}$ of deionized water and stirred in an orbital shaker (100 rpm, $15 \mathrm{~min})$. Afterwards, $1.5 \mathrm{~mL}$ of the DPPH solution $(0.1 \mathrm{mM}$, in ethanol 95\%) was added in the dark, under stirring at $100 \mathrm{rpm}$ for $30 \mathrm{~min}$ before spectrophotometric reading $(517 \mathrm{~nm})$. Trolox (6-hydroxy-2,5,7,8-tetramethylchroman-2-carboxylic acid) was used as a standard and deionized water as a blank. The AA was expressed in trolox equivalent ( $\mu$ mols Trolox Eq by gram of protein).

Cytotoxicity assessment using intestinal epithelial cells

\section{Cell culture}

The human colon carcinoma Caco-2 cell line (ATCC, HTB-37) was used at passages 25-40. Caco-2 cells were grown in culture flasks containing Minimum Essential Medium (MEM), supplemented with $20 \%$ (v/v) fetal bovine serum, $0.11 \mathrm{mg} / \mathrm{mL}$ sodium pyruvate, $1 \%(\mathrm{v} / \mathrm{v})$ non-essential amino acids and $1 \%(\mathrm{v} / \mathrm{v})$ penicillin/streptomycin. The cells were kept at $37{ }^{\circ} \mathrm{C}$ in $5 \% \mathrm{CO}_{2}$ water-saturated atmosphere. 
Cytotoxicity — cell viability assessment using

the resazurin assay

The resazurin assay was used to assess the cellular viability of Caco-2, after incubation with BCNF-based films (Ahmed et al. 1994; Nowak et al. 2017; Xu et al. 2015). Resazurin dye is a cell permeable redox indicator that has been broadly used as an indicator of cell viability in proliferation and cytotoxicity assays (Nociari et al. 1998). Viable cells with active metabolism can reduce resazurin into the resorufin product, which is pink and fluorescent. The quantity of resorufin produced is proportional to the number of viable cells.

Caco- 2 cells were seeded onto 96-wells plate at a density of 10,000 cells per well and left adhering overnight. After adhesion, the culture medium was removed and replaced by the BCNF-based films or individual components, diluted in the culture medium.

The BCNF-based films were first dispersed in ultrapure water (milli-Q) using the Ultra-Turrax homogenizer at $3000 \mathrm{rpm}$ for $1 \mathrm{~min}$, then sonicated in ultrasonic bath for $15 \mathrm{~min}(37 \mathrm{kHz}$ and 104 Watt) and finally exposed to ultraviolet lamp during $30 \mathrm{~min}$ for sterilization. The water dispersions of BCNFbased films or the control compounds were diluted in the culture medium $(10 \%, \mathrm{v} / \mathrm{v})$ to obtain the test concentrations. A negative control was performed using cells growing in the culture medium (considered as $100 \%$ cell viability). DMSO (40\% v/v) was used as a positive control. The samples were incubated for $24 \mathrm{~h}$ or $48 \mathrm{~h}$ with $10 \%$ (v/v) resazurin solution (final concentration $0.01 \mathrm{mg} / \mathrm{mL}$ ). Resazurin was added simultaneously with samples, since it is not toxic providing adequate sensitivity (Ahmed et al. 1994; Xu et al. 2015). For all samples, a blank was performed using samples diluted in the culture medium and incubated with resazurin (without cells).

The fluorescence intensity, that is proportional to the cell viability, was measured using a Microplate Fluorescence Reader (Synergy, BioTek H1, USA) at an excitation wavelength of $560 \mathrm{~nm}$ and an emission wavelength of $590 \mathrm{~nm}$. The \% cell viability was expressed as fluorescence of cells treated with samples compared to the fluorescence of cells growing in the culture medium ( $100 \%$ cell viability) as follows:

$\%$ Cell Viability $=\left[\frac{F_{T C}-F_{S}}{F_{C}-F_{C M}}\right] \times 100$ where $\mathrm{F}_{\mathrm{TC}}$ is the fluorescence of treated cells, $\mathrm{F}_{\mathrm{S}}$ is the fluorescence of sample in the culture medium (without cells), $\mathrm{F}_{\mathrm{C}}$ is the fluorescence of cells growing in the culture medium, $\mathrm{F}_{\mathrm{CM}}$ is the fluorescence of culture medium (without cells).

Statistical analysis

The statistical analysis was carried out using the software Origin Pro 9.0 (OriginLab Corporation). The statistical significance of the evaluated data was analyzed by one-way analysis of variance (ANOVA) and the Tukey's test with significance level $(\alpha)=0.1$.

\section{Results and discussion}

Effect of plasticizers on properties of BCNF-based films

The effect of plasticizers was evaluated on the mechanical properties, water vapor permeability, water solubility, crystallinity and thermal behavior of BCNF-HS based films (Table 2). The plasticizers sorbitol and glycerol were added to improve mechanical properties and facilitate handling of the films (BCNF-HS-S and BCNF-HS-G, respectively). Once the BCNF-HS films exhibited high brittleness behavior, the mechanical tests were performed only with those containing plasticizers. Films with glycerol exhibited a Young's modulus $(E)$ 28.16\% lower and an elongation at break (c) $37.20 \%$ higher than the films using sorbitol as plasticizer (Table 2). This result may be related to the superior capacity of glycerol to act as a plasticizer, which is explained by its lower molecular weight and ability to improve water incorporation (Csiszár and Nagy 2017; Cerqueira et al. 2012a). The $E$ reduction and $\varepsilon$ increase observed for glycerol containing films when compared to sorbitol, were also observed by Thomazine et al. (2006) for gelatin-based films.

TEMPO-oxidized cellulose nanofibers provide good mechanical properties assigned to the dense and strong cellulose network (Rodinova et al. 2012; Wu and Cheng 2017). BCNF-HS-S films exhibited higher tensile strength than several polymeric films reported in the literature, such as alginate/cellulose nanofibers (Deepa et al. 2016), starch (Moreno et al. 
2015; Piñeros-Hernandez et al. 2017; Yunos and Rahman 2011), kappa-carrageenan (Farhan and Hani 2017), gelatin (Thomazine et al. 2006; Tongnuanchan et al. 2012, 2015), gelatin/dialdehyde carboxymethyl cellulose (Mu et al. 2012), and chitosan (Cerqueira et al. 2012b; Soni et al. 2016). Regarding the elongation at break $(\varepsilon)$, the value obtained for BCNF-HS-S films is higher than kappa-carrageenan films (Farhan and Hani 2017) and microfibrillar cellulose (Syverud and Stenius 2009).

Crystallinity degree $\left(\mathrm{C}_{\mathrm{D}}\right)$ of unplasticized and plasticized films was similar (Table 2). X-ray diffraction profiles revealed high crystallinity degree, similar to those reported elsewhere for bacterial cellulose (Campano et al. 2016).

In the thermal behaviour it was found that the addition of sorbitol or glycerol into the BCNF-HS films reduced the $\mathrm{T}_{\text {onset }}$ from 252 to $221{ }^{\circ} \mathrm{C}$ or $172{ }^{\circ} \mathrm{C}$, respectively, and leads to the appearance of new derivative-thermogravimetric (DTG) peaks (Fig. 1, Table 2). Multiple DTG peaks are assigned to the presence of non-cellulose compounds, such as proteins or metabolic compounds from microbial growth (Gea et al. 2011). Typical events of BC degradation were observed around $330{ }^{\circ} \mathrm{C}$ (Fig. 1) in all films, with or without plasticizers. Fukuzumi et al. (2009) and Fukuzumi et al. (2010) reported that films of TEMPOoxidized cellulose nanofibers exhibited $\mathrm{T}_{\text {onset }}$ from 200 to $222{ }^{\circ} \mathrm{C}$, therefore close to BCNF-HS-S value obtained in this study and lower than BCNF-HS.

The thermal stability is associated with plasticizers type and their interaction with the polymer. Films containing glycerol (BCNF-HS-G films) exhibit lower $\mathrm{T}_{\text {onset }}$ than those with sorbitol (BCNF-HS-S films) (Table 2). Sorbitol has more hydroxyl groups available to interact with cellulose by hydrogen bonds, leading to better thermal stability when compared to films with glycerol. It has been reported that glycerol exhibits a lower value of $\mathrm{T}_{\text {onset }}$ and DTG peak than oxidized cellulose, as observed in this work for the BCNF-HS-G films (Ciriminna et al. 2014; GómezSiurana et al. 2012; Yunos and Rahman 2011). With respect to the film containing sorbitol (BCNF-HS-S) it presents a lower $\mathrm{T}_{\text {onset }}\left(215^{\circ} \mathrm{C}\right)$ than separated components $\left(251{ }^{\circ} \mathrm{C}\right.$ for BCNF-HS and $257^{\circ} \mathrm{C}$ for sorbitol).

The water solubility (WS) gives an indication of the films' stability when they are in a high hydrophilic medium. The plasticizers have a great influence in the WS since BCNF-HS films present WS values close to

Table 2 Mechanical properties of BCNF-based films

\begin{tabular}{|c|c|c|c|c|c|}
\hline Film & BCNF-HS & BCNF-HS-S & BCNF-HS-G & BCNF-HS-S-GH & BCNF-CM-S-GH \\
\hline$E(\mathrm{GPa})$ & $* *$ & $1.42^{\mathrm{a}} \pm 0.13$ & $1.02^{\mathrm{b}} \pm 0.11$ & $0.57^{\mathrm{c}} \pm 0.05$ & $0.50^{\mathrm{c}} \pm 0.07$ \\
\hline$\sigma(\mathrm{Mpa})$ & $* *$ & $87.04^{\mathrm{a}} \pm 12.70$ & $78.43^{\mathrm{a}} \pm 10.02$ & $26.27^{\mathrm{b}} \pm 3.75$ & $45.72^{\mathrm{c}} \pm 7.71$ \\
\hline$\varepsilon(\%)$ & $* *$ & $12.47^{\mathrm{a}} \pm 1.87$ & $17.11^{\mathrm{b}} \pm 2.29$ & $9.60^{\mathrm{a}} \pm 1.09$ & $30.40^{c} \pm 7.49$ \\
\hline $\mathrm{T}_{\text {onset }}\left({ }^{\circ} \mathrm{C}\right)$ & 252 & 221 & 172 & 206 & 256 \\
\hline DTG peaks $\left({ }^{\circ} \mathrm{C}\right)$ & 333 & $330 / 274 / 231$ & $333 / 239 / 201$ & $314 / 262 / 144$ & $347 / 287$ \\
\hline $\mathrm{C}_{\mathrm{D}}(\%)$ & 84 & 82 & 83 & 75 & 82 \\
\hline WS $(\%)$ & n.d & $34.68^{\mathrm{a}} \pm 6.10$ & $69.58^{\mathrm{b}} \pm 5.95$ & $59.54^{\mathrm{c}} \pm 5.00$ & $78.46^{\mathrm{d}} \pm 6.76$ \\
\hline WVP (g.mm/kPa.h.m²) & $0.48^{\mathrm{a}} \pm 0.03$ & $0.93^{\mathrm{b}} \pm 0.08$ & $1.00^{\mathrm{b}} \pm 0.12$ & $1.54^{\mathrm{c}} \pm 0.08$ & $1.58^{\mathrm{c}} \pm 0.14$ \\
\hline Contact angle $\left(^{\circ}\right)$ & $41.53^{\mathrm{a}} \pm 5.62$ & $65.72^{b c} \pm 10.70$ & $71.72^{\mathrm{c}} \pm 9.27$ & $58.75^{\mathrm{ab}} \pm 11.95$ & $40.75^{\mathrm{a}} \pm 7.32$ \\
\hline $\mathrm{AA}(\mu \mathrm{mols} \mathrm{TEAC} / \mathrm{g}$ of protein $)$ & n.d & n.d & n.d & $7.80^{\mathrm{a}} \pm 1.60$ & $7.29^{\mathrm{a}} \pm 0.46$ \\
\hline $\mathrm{T}(\mathrm{n} / \mathrm{a})$ & $0.18^{\mathrm{a}} \pm 0.00$ & $0.62^{\mathrm{b}} \pm 0.01$ & $1.00^{c} \pm 0.04$ & $1.02^{\mathrm{c}} \pm 0.02$ & $1.00^{c} \pm 0.03$ \\
\hline$L^{*}$ & $90.39^{\mathrm{ab}} \pm 0.01$ & $90.12^{\mathrm{a}} \pm 0.36$ & $93.2^{\mathrm{c}} \pm 0.27$ & $88.99^{\mathrm{b}} \pm 0.82$ & $87.74^{\mathrm{b}} \pm 1.03$ \\
\hline$a^{*}$ & $4.73^{\mathrm{ab}} \pm 0.08$ & $4.5^{\mathrm{c}} \pm 0.08$ & $-0.04^{\mathrm{d}} \pm 0.09$ & $5.05^{\mathrm{b}} \pm 0.23$ & $4.76^{\mathrm{a}} \pm 0.11$ \\
\hline$b^{*}$ & $6.73^{\mathrm{a}} \pm 0.43$ & $7.28^{\mathrm{a}} \pm 1.08$ & $10.68^{b} \pm 0.46$ & $10.69^{\mathrm{b}} \pm 2.57$ & $12.33^{\mathrm{c}} \pm 1.86$ \\
\hline
\end{tabular}

Means in the same line with different superscript letters are significantly different $(P<0.1)$

$E$ Young's modulus, $\sigma$ tensile strength, $\varepsilon$ elongation at break, $T_{\text {onset }}$ and DTG peaks thermal properties, $C_{\mathrm{D}}$ crystallinity degree, $W V P$ water vapor permeability, WS water solubility, $A A$ antioxidant activity, $T$ transparency, color parameters $\left(\mathrm{L}^{*} / \mathrm{a} * / \mathrm{b}^{*}\right)$

*The brittleness of films could not be analyzed

**Not performed and $n . d$ Non-detected 

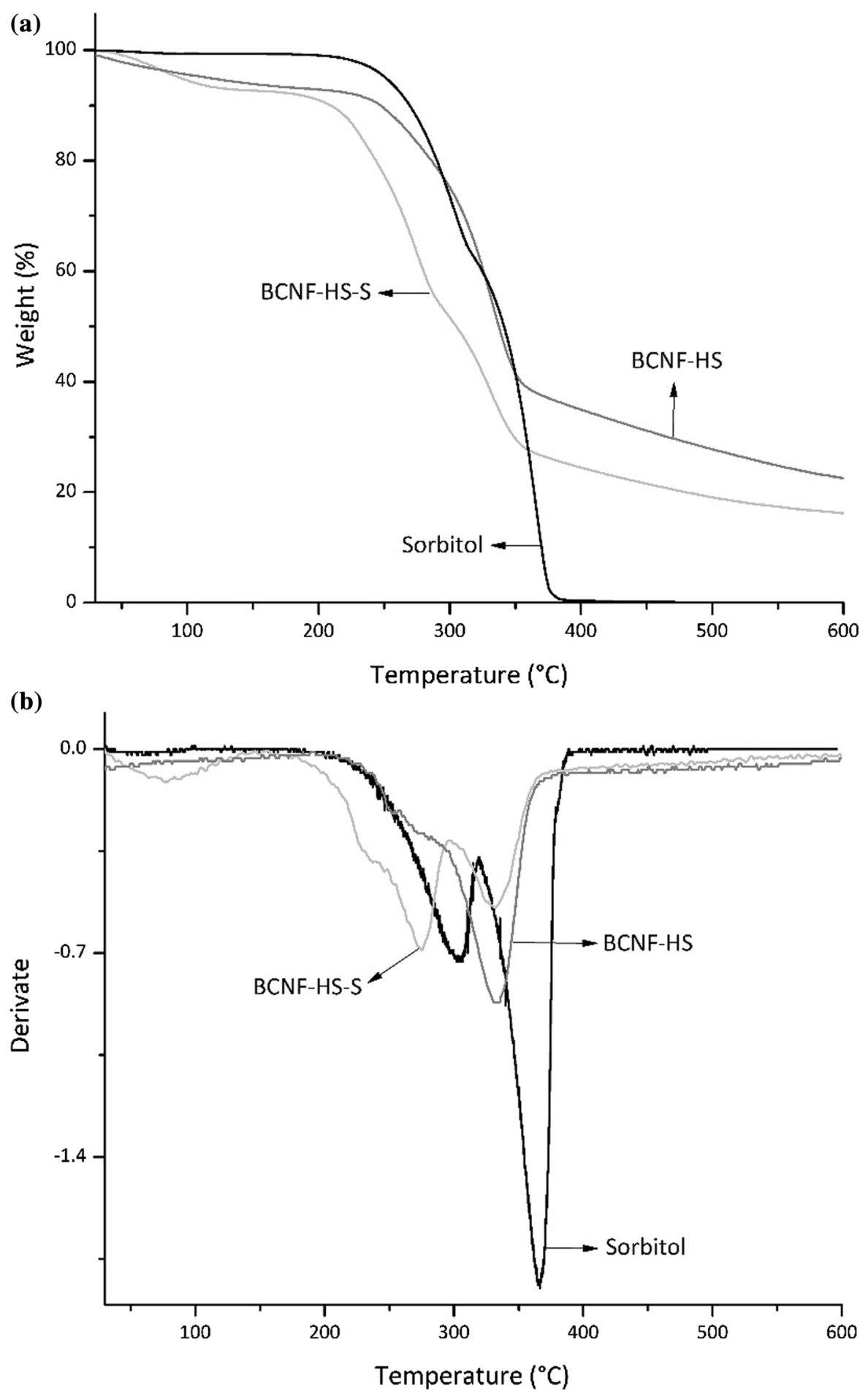

Fig. 1 a Thermogravimetric (TG) and b derivative thermogravimetric (DTG) curves of BCNF-based film containing sorbitol (BCNFHS-S) and its components (sorbitol and BCNF-HS) 
zero while plasticized films (BCNF-HS-S) exhibit a weight loss of $34.68 \%$, close to the amount of sorbitol present in the films (Table 1), suggesting that it is totally released during the WS assay. Meanwhile, BCNF-HS-G had a higher solubility $(69.58 \%)$ when compared to BCNF-HS-S. Deepa et al. (2016) mentioned that the intensity of hydrogen bonding between the components of a composite influences its solubility and water resistance which in this case can be justified by the plasticizer type, as previously explained.

Regarding the WVP values, both films, BCNF-HS$\mathrm{S}$ and BCNF-HS-G, exhibited similar values of WVP $(P>0.1)$, which are $93.75 \%$ and $108.33 \%$ higher, than the films without plasticizer (BCNF-HS) (Table 2). This effect is explained by the hydrophilic behavior of plasticizers, which due their hydroxyl groups and low molecular weight exhibit capacity to create regions of higher water mobility in polymer and thus contributing to the increase of water diffusion, hence increasing WVP (Cao et al. 2009). The WVP increase was also observed by Farhan and Hani (2017) after addition of sorbitol or glycerol into carrageenan films and by Nur Hanani et al. (2013) in gelatin films.

The hydrophilicity of films was confirmed by measuring the contact angle. All films exhibited contact angles lower than $90^{\circ}$ revealing their hydrophilic feature. After plasticization, regardless of the plasticizer used, an increase in the contact angle was observed. This may be related to the formation of hydrogen bonding between plasticizers and cellulose, leading to a reduction in the number of exposed hydroxyl groups that previously remained free for interactions with water as previously reported by $\mathrm{CaO}$ et al. (2009).

BCNF-based films containing sorbitol showed the higher $E$, lower WS and higher thermal stability. Based on these results, the BCNF-based films containing sorbitol were selected for the further incorporation of gelatin hydrolysate $(\mathrm{GH})$.

Characterization of BCNF-based films

incorporating gelatin hydrolysate

\section{Thermal and mechanical properties}

The effect of gelatin hydrolysate incorporation into the BCNF-HS-S films on the thermal properties of films was evaluated. Figure 2 shows the thermogravimetric (TG) and derivative thermogravimetric (DTG) curves of films containing $\mathrm{GH}$ in comparison with films without $\mathrm{GH}$. The $\mathrm{T}_{\text {onset }}$ was reduced from 221 to $206{ }^{\circ} \mathrm{C}$, after $\mathrm{GH}$ incorporation. Moreover, three different DTG peaks are detected $\left(315,262\right.$ and $\left.144{ }^{\circ} \mathrm{C}\right)$ assigned to non-cellulose compounds (Table 2). In the literature, Hoque et al. (2011) observed a reduction on mechanical and thermal properties of gelatin/glycerol films when replacing gelatin with gelatin hydrolysate. This behaviour was explained by the protein structure breakdown caused by reducing protein-protein and matrix-protein interactions.

Regarding the mechanical properties, the incorporation of GH into the BCNF-HS-S films lead to the decrease of $E$ by $59.85 \%$ and the tensile strength by $69.81 \%$, reaching $0.57 \mathrm{GPa}$ and $26.27 \mathrm{MPa}$, respectively (Table 2). The addition of peptides or proteins have been reported to decrease $\sigma$ due to the weakness of cohesive properties (Pei et al. 2013; Ferreira et al. 2009), in good agreement with the results obtained in this work. It has also been referred that peptides and hydrolysates can exhibit a plasticizer effect (Nuanmano et al. 2015; Ferreira et al. 2009), which was not observed in this study since $\varepsilon$ was not significantly modified. Each particular combination of matrix, plasticizer and protein hydrolysate yields different properties according to the strength of the intermolecular interactions.

Although the incorporation of $\mathrm{GH}$ into BCNFbased films affected $E$ and $\sigma$ to some extent, the mechanical properties of the films produced remain suitable for several food applications. In fact, BCNFHS-S-GH films exhibited higher tensile strength than several polymeric films reported in the literature, such as starch (Moreno et al. 2015; Piñeros-Hernandez et al. 2017; Yunos and Rahman 2011), chitosan (Cerqueira et al. 2012b; Soni et al. 2016), gelatin/glycerol (Nur Hanani et al. 2013), fish skin gelatin/palm oil (Tongnuanchan et al. 2015), gelatin/dialdehyde carboxymethyl cellulose (Mu et al. 2012), and gelatin/ glycerol/sorbitol (Thomazine et al. 2006). The $E$ obtained is higher than gelatin/glycerol/sorbitol films reported by Thomazine et al. (2006).

\section{Morphology}

All BCNF-based films bear a similar dense appearance that prevents the visualization of nanofibers by SEM (Fig. 3). The drying expressively affected the nanofibers compaction that is essential to form strong films. 

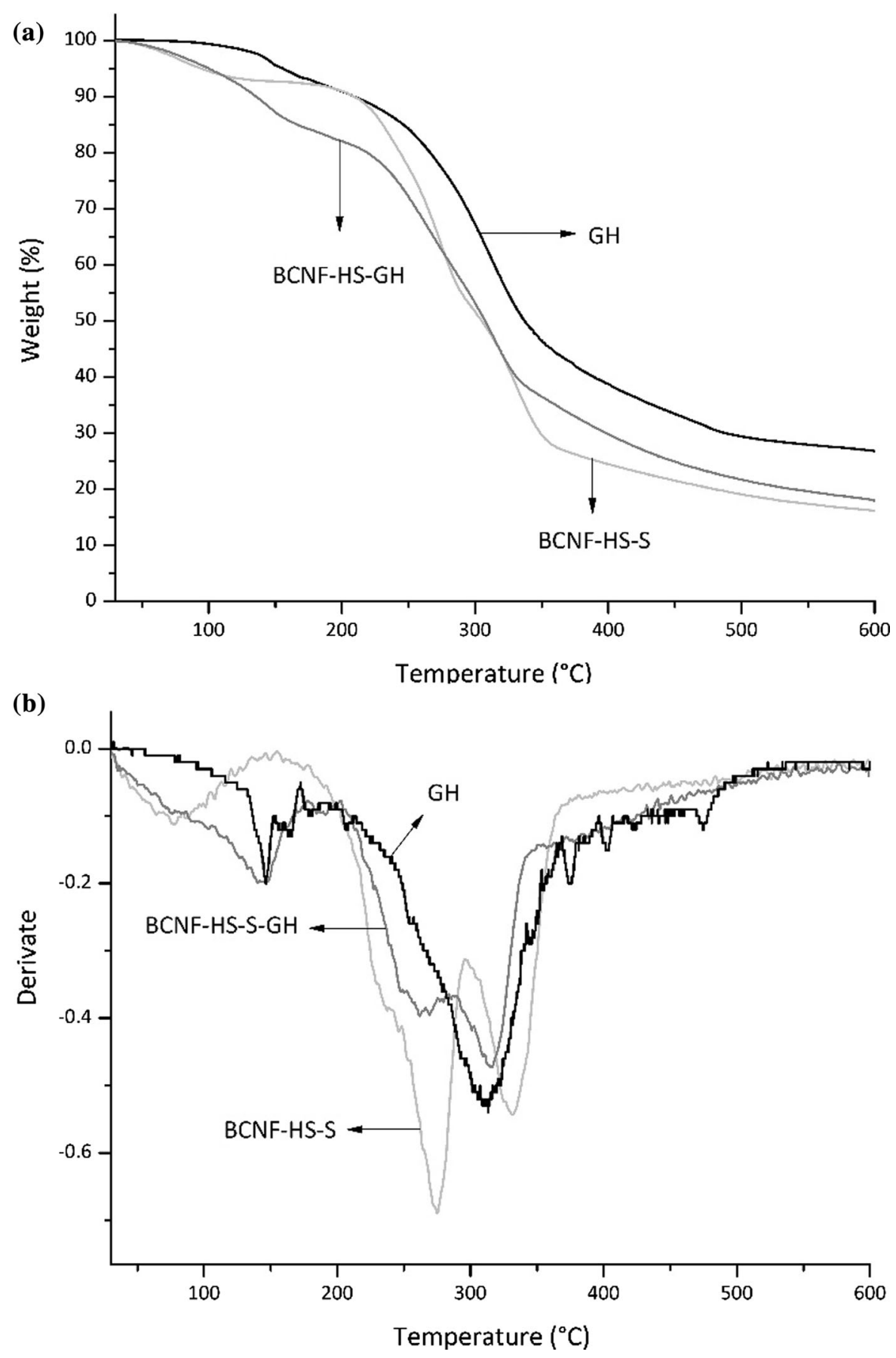

Fig. 2 a Thermogravimetric (TG) and b derivative thermogravimetric (DTG) curves of gelatin hydrolysate (GH) and BCNF-based films: BCNF-HS-S and BCNF-HS-S-GH 
BCNF-HS-S-GH film appears to be less homogeneous than others due to the formation of aggregates, probably caused by GH proteins as observed by Lin et al. (2015a, b) and Gao et al. (2014) in bacterial cellulose/protein composites.

Water vapor permeability (WVP), water solubility (WS) and contact angle

The addition of gelatin hydrolysate $(\mathrm{GH})$ to the films lead to an increase of water solubility when compared with films without $\mathrm{GH}$, from $34.58 \%$ to $59.54 \%$ (Table 2). This value is close to the amount of sorbitol and $\mathrm{GH}$ present in the film composition (60\%), indicating that these compounds are probably fully solubilized during the test. In fact, sorbitol and gelatin hydrolysates are soluble in water. Regarding the WVP of BCNF-HS-S-GH films, a value of 1.54 g.mm/ $\mathrm{kPa} . \mathrm{h} . \mathrm{m}^{2}$ was obtained, being the value $65.59 \%$ higher to the films without GH (0.93 g.mm/kPa.h.m², Table 2). The hydrophilicity and hygroscopicity of GH probably contributed to the higher WVP due to the increase of water-vapor adsorption promoted by polar groups $\left(-\mathrm{COOH},-\mathrm{NH}_{2}\right.$ and $\left.-\mathrm{OH}\right)$ (Nuanmano et al. 2015). Hermansyah et al. (2013) reported the poor water barrier properties of gelatin and Ferreira et al. (2009) observed an increase in WVP of chitosan films after protein addition. The WVP observed for BCNFHS-S-GH films is similar to the values presented for the WVP of other natural composites/polymers, such as alginate (Benavides et al. 2012; Olivas et al. 2008; Rhim, 2004), chitosan (Azeredo et al. 2010), gelatin (Santos et al. 2014), starch (Piñeros-Hernandez et al. 2017; Bertuzzi et al. 2007), whey protein and zein (Baldwin et al. 2012).

After $\mathrm{GH}$ incorporation, it was observed a reduction in the exhibited contact angle, which was $58.75^{\circ}$ for BCNF-HS-S-GH versus $65.72^{\circ}$ for BCNF-HS-S. The hydrophilicity was increased after $\mathrm{GH}$ incorporation probably due to excess of polar groups that weakened interactions between hydrophilic groups of cellulose, sorbitol and GH as reported by Cao et al. (2009) in their studies with gelatin films.

\section{FTIR and X-ray diffraction (XRD)}

FTIR spectra of studied films exhibited typical vibration bands of cellulose (Fig. 4 a, b): O-H bond stretching $\left(3345 \mathrm{~cm}^{-1}\right)$, asymmetric stretching of

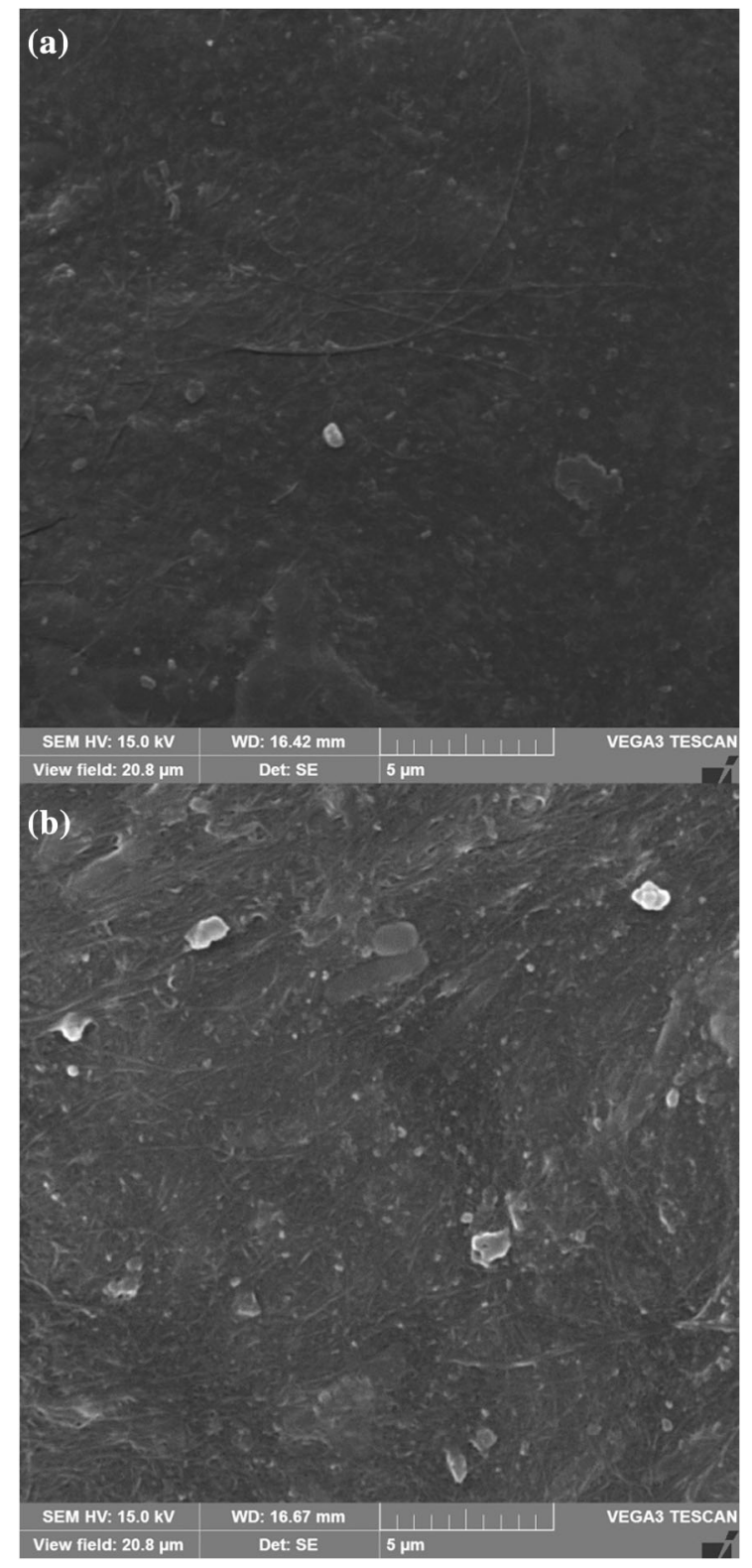

Fig. 3 Scanning electron microscopy images of BCNF-based films. a BCNF-HS-S and b BCNF-HS-S-GH

$\mathrm{CH}_{2}$ (2920-2850 $\mathrm{cm}^{-1}$ ), asymmetric angular deformation of $\mathrm{C}-\mathrm{H}$ bonds $\left(1426 \mathrm{~cm}^{-1}\right)$, symmetric angular deformation of $\mathrm{C}-\mathrm{H}$ bonds $\left(1360-1378 \mathrm{~cm}^{-1}\right)$, asymmetrical stretching of $\mathrm{C}-\mathrm{O}-\mathrm{C}$ glycosidic bonds $\left(1160 \mathrm{~cm}^{-1}\right)$, stretching of $\mathrm{C}-\mathrm{OH}$ and $\mathrm{C}-\mathrm{C}-\mathrm{OH}$ bonds for secondary and primary alcohols respectively (1107-1055 $\mathrm{cm}^{-1}$ ), C-H bond bending or $\mathrm{CH}_{2}$ stretching $\left(900 \mathrm{~cm}^{-1}\right)$, and $\mathrm{O}-\mathrm{H}$ out-of-plane bending $\left(665 \mathrm{~cm}^{-1}\right)$. BCNF-HS-S-GH films presented an 
Fig. 4 a, b FTIR spectra and $\mathbf{c} X$-ray diffractograms of BCNF-based films: BCNF-HS-S and BCNFHS-S-GH
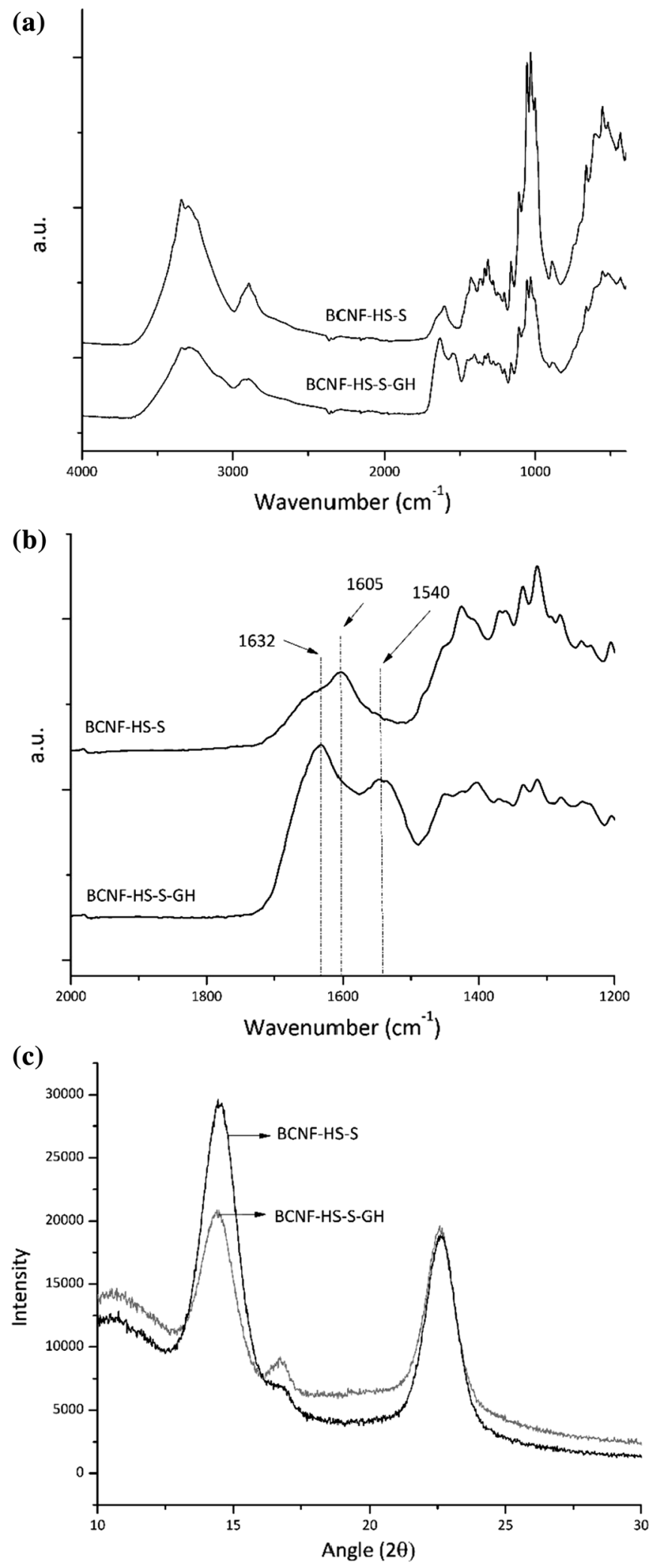
intense band at approximately $1700-1500 \mathrm{~cm}^{-1}$ related to nitrogen and protein structures: $\mathrm{C}=\mathrm{O}$ stretching in type I amides $\left(1632 \mathrm{~cm}^{-1}\right)$ and angular deformation in type II amides $\left(1540 \mathrm{~cm}^{-1}\right)($ Gea et al. 2011), due to the presence of GH. $1605 \mathrm{~cm}^{-1}$ band related to $\mathrm{C}=\mathrm{O}$ stretching of $\mathrm{COONa}(\mathrm{Wu}$ and Cheng 2017) in BCNF-HS and BCNF-HS-S films is slightly more intense than in BCNF-HS-S-GH which can be explained by the lower amount of TEMPO-oxidized cellulose (BCNFs) (Table 1).

The $C_{D}$ value was slightly reduced $(10.7 \%)$ in BCNF-HS-S-HG film when compared to BCNF-HS-S, although still high and characteristic of BC (Campano et al. 2016) (Fig. 4c). This expressive reduction may have occurred due to a possible interaction of the gelatin hydrolyzate added with the bacterial cellulose nanofibrils. Zhijiang and Guang (2010) also reported a reduction in the crystallinity index of BC films with addition of collagen. They assume that the interaction of collagen with $\mathrm{BC}$ must have disturbed the regular arrangement of $\mathrm{BC}$ molecule chains, which in turn can decrease the crystallinity index. Also, this rearrangement in the disposition of nanofibrils may have contributed to the reduction of mechanical properties of BCNF-HS-S-HG film versus BCNF-HS-S film (Table 2), discussed previously in item 3.2.1.

\section{Transparency and color}

BCNF-based films containing sorbitol and antioxidant hydrolysate presented higher transparency than films made of BCNFs only, probably due to a better packing of the film with additives filling the space between the fibers, hence impacting on the refraction of light. BCNF-HS-S-GH films exhibited a slightly yellower color $\left(b^{*}\right)$ when compared to others (Table 2). This increase on yellow coloration in BCNF-based films with crude hydrolysates might be related to creamy yellowish color of hydrolyzed gelatin that may be related to the presence of compounds produced in the Maillard reaction, between carbonyl groups resultant of lipid oxidation (e.g. aldehydes and ketones) and amino groups of free amino acids or peptides (Schmid et al. 2013).

Effect of the BCNF source on the film properties

Aiming to investigate the potential of application of $\mathrm{BC}$ obtained in a medium of low cost culture, the cashew apple juice was selected as an alternative medium. Films containing sorbitol and gelatin hydrolyzate produced using BCNFs derived from the cashew apple juice medium (BCNF-CM-S-GH) exhibited WVP, $E$, transparency, contact angle, $b^{*}$ color parameter, and antioxidant activity statistically similar to films of BCNFs derived from synthetic medium HS (BCNF-HS-S-GH), as shown in Table 2. Moreover, the tensile strength, elongation at break, crystallinity degree, $\mathrm{T}_{\text {onset }}$ and WS of BCNF-CM-SGH were increased by $74.03,216.66,8.44,24.27$, and $31.76 \%$, respectively, when compared to BCNF-HSS-GH film. Recent findings in the literature have reported that changes in characteristics such as degree of polymerization and intermolecular arrangement of BC molecule chains, influenced by type of culture medium, contribute to differences in BC properties such as the mechanical properties and crystallinity (Campano et al. 2016; Zhijiang and Guang 2010). Thus, structural changes in BC produced in cashew medium must have contributed to the properties of BCNF-CM-S-GH films.

Cytotoxicity—cell viability through resazurin assay

The biocompatibility of materials is routinely evaluated using in vitro methodologies. Cell lines are often cultivated in contact with test materials, and after a variable period, the cellular metabolic activity, proliferation and/or death rates are measured (Gosslau 2016). In this study, a resazurin solution was used to assess the cellular viability of Caco-2 after incubation with BCNF-based films or with the respective controls.

As shown in Fig. 5, the BCNF-based films or the individual components (plasticizer, hydrolysate or bacterial cellulose nanofibers) had no effect on the metabolic activity of Caco-2 cells, irrespective of the incubation period. All samples exhibit high cell viability up to $48 \mathrm{~h}$ of incubation demonstrating the biocompatibility of the produced BCNF-based films. The use of BCNFs, as a carrier of bioactive compounds in food applications, turns the toxicological assessment mandatory. The results of this study indicate that the tested BCNF-based films by themselves are not cytotoxic, thus appropriate for use in food or packaging applications. 
Fig. 5 Cellular viability of Caco-2 after incubation (24 and $48 \mathrm{~h}$ ) with BCNF-based films or with the respective controls. Controls: (-) cells incubated with $10 \%$ milli-Q (negative control); $(+)$ cells incubated with $40 \%$ of DMSO (positive control). Data shown mean $\pm \mathrm{SD}$, $\mathrm{n}=8$

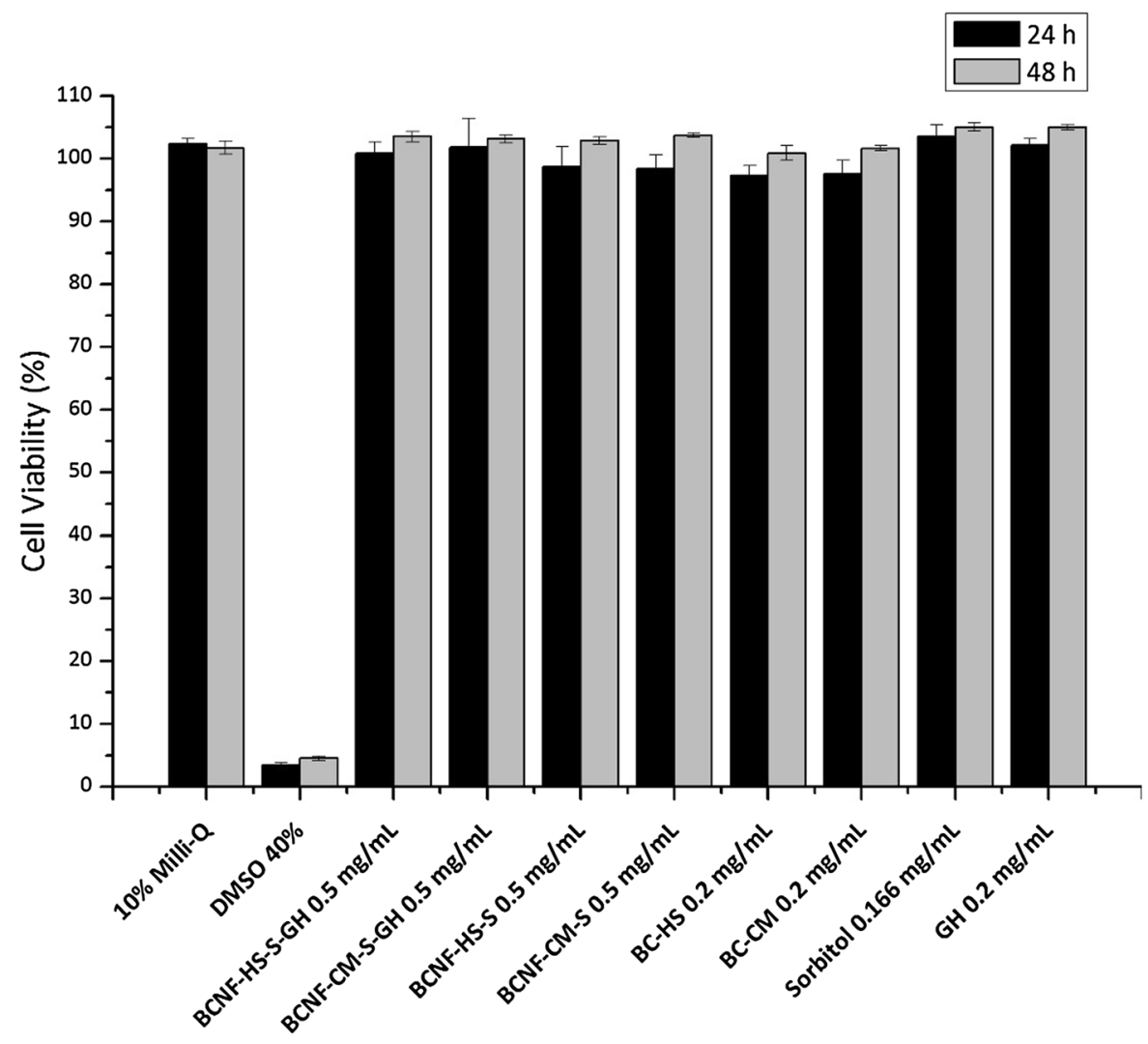

\section{Conclusions}

Antioxidant films based on bacterial cellulose nanofibers (BCNFs), plasticizers (glycerol and sorbitol) and tilapia skin gelatin hydrolysate $(\mathrm{GH})$ were successfully produced. Films plasticized with sorbitol exhibited better performance than glycerol, regarding water solubility, Young's modulus and thermal properties. Although, the incorporation of GH into BCNFbased films affected their properties, the present work demonstrated that the produced films present antioxidant activity and have improved characteristics compared to similar polymeric films reported in the literature. The replacement of BCNFs from synthetic culture medium by BCNFs from cashew apple juice medium, used for the films production, improved their tensile strength, elongation at break, thermal stability, and crystallinity degree. This implies that the $\mathrm{BC}$ of cashew medium allows the production of films with improved features arising as a low cost alternative to synthetic medium. The cytotoxicity assessment demonstrated that BCNF-based films are non-cytotoxic, reinforcing their potential for food applications.

Acknowledgments The authors would like to thank: Foundation of Support to the Scientific and Technological Development (FUNCAP, Brazil), Coordination for the Improvement of Higher Education Personnel (CAPES, Brazil), National Counsel of Technological and Scientific Development (CNPq, Brazil), Minho University (Braga, Portugal) and International Iberian Nanotechnology Laboratory (Braga, Portugal). This work was funded by research projects $\mathrm{CNPq} \mathrm{n}^{\circ} 485465 / 2012-4, \quad \mathrm{CNPq} \mathrm{n}^{\circ}$ 310368/2012-0 and CNPq $n^{\circ}$ 476978/2013-0. Funding from Fundação para a Ciência e Tecnologia through the project "Bacterial Cellulose: a platform for the development of bionanoproducts", under the bilateral program FCT/CAPES, is acknowledged. The authors acknowledge also the funding from QREN ("Quadro de Referência Estratégica Nacional"), ADI ("Agência de Inovação") through the project Norte-070202-FEDER-038853, and BioTecNorte operation (NORTE01-0145-FEDER-000004) funded by the European Regional Development Fund under the scope of Norte2020-Programa Operacional Regional do Norte. This research was supported by Norte Regional Operational Program 2014-2020 (Norte2020) through the European Regional Development Fund (ERDF) Nanotechnology based functional solutions (NORTE-01-0145FEDER-000019). 


\section{References}

Ahmed SA, Gogal RM, Walsh JE (1994) A new rapid and simple non-radioactive assay to monitor and determine the proliferation of lymphocytes: an alternative to $[3 \mathrm{H}]$ thymidine incorporation assay. J Immunol Methods 170:211224. https://doi.org/10.1016/0022-1759(94)90396-4

Albuquerque PBS, Cerqueira MA, Vicente AA et al (2017) Immobilization of bioactive compounds in Cassia grandis galactomannan-based films: influence on physicochemical properties. Int J Biol Macromol 96:727-735. https://doi. org/10.1016/j.ijbiomac.2016.12.081

Anthis NJ, Clore GM (2013) Sequence-specific determination of protein and peptide concentrations by absorbance at 205 nm. Protein Sci 22:851-858. https://doi.org/10.1002/pro. 2253

ASTM (1989) Standard test methods for water vapor transmission of materials E96-80. In: Annual book of American Standard Testing Methods. ASTM, Philadelphia

ASTM (1997) Standard test method for tensile properties of thin plastic sheeting. D882. In: Annual book of American Standard Testing Methods. ASTM, Philadelphia. pp 162-170

Atarés L, Chiralt A (2016) Essential oils as additives in biodegradable films and coatings for active food packaging. Trends Food Sci Technol 48:51-62. https://doi.org/10. 1016/j.tifs.2015.12.001

Azeredo HMC, Mattoso LHC, Avena BRJ et al (2010) Nanocellulose reinforced chitosan composite films as affected by nanofiller loading and plasticizer content. J Food Sci 75:N1-N7. https://doi.org/10.1111/j.17503841.2009.01386.x

Baldwin EA, Hagenmaier RD, Bai J (2012) Edible coatings and films to improve food quality. CRC Press, Boca Raton

Bauer AK, Dwyer NLD, Hankin JA et al (2001) The lung tumor promoter, butylated hydroxytoluene (BHT), causes chronic inflammation in promotion-sensitive BALB/cByJ mice but not in promotion-resistant CXB4 mice. Toxicology 169: 1-15. https://doi.org/10.1016/S0300-483X(01)00475-9

Benavides S, Villalobos CR, Reyes JEE (2012) Physical, mechanical and antibacterial properties of alginate film: effect of the crosslinking degree and oregano essential oil concentration. J Food Eng 110:232-239. https://doi.org/10. 1016/j.jfoodeng.2011.05.023

Bertuzzi MA, Castro Vidaurre EF, Armada M, Gottifredi JC (2007) Water vapor permeability of edible starch based films. J Food Eng 80:972-978. https://doi.org/10.1016/j. jfoodeng.2006.07.016

Campano C, Balea A, Blanco A, Negro C (2016) Enhancement of the fermentation process and properties of bacterial cellulose: a review. Cellulose 23:57-91. https://doi.org/10. 1007/s10570-015-0802-0

Cao N, Yang X, Fu Y (2009) Effects of various plasticizers on mechanical and water vapor barrier properties of gelatin films. Food Hydrocoll 23:729-735. https://doi.org/10. 1016/j.foodhyd.2008.07.017

Cerqueira MA, Souza BWSS, Teixeira JA, Vicente AA (2012a) Effect of glycerol and corn oil on physicochemical properties of polysaccharide films - a comparative study. Food
Hydrocoll 27:175-184. https://doi.org/10.1016/j.foodhyd. 2011.07.007

Cerqueira MA, Souza BWS, Teixeira JA, Vicente AA (2012b) Effects of interactions between the constituents of chitosan-edible films on their physical properties. Food Bioprocess Technol 5:3181-3192. https://doi.org/10.1007/ s11947-011-0663-y

Chawla PR, Bajaj IB, Survase SA, Singhal RS (2009) Microbial cellulose: fermentative production and applications prashant. Food Technol Biotechnol 47:107-124

Chi CF, Wang B, Wang YM et al (2015) Isolation and characterization of three antioxidant peptides from protein hydrolysate of bluefin leatherjacket (Navodon septentrionalis) heads. J Funct Foods 12:1-10. https://doi.org/10. 1016/j.jff.2014.10.027

Ciriminna R, Pantaleo G, Mattina R, Pagliaro M (2014) Thermogravimetric investigation of sol-gel microspheres doped with aqueous glycerol. Sustain Chem Process 2:26. https://doi.org/10.1186/s40508-014-0026-x

Coelho CCS, Michelin M, Cerqueira MA et al (2018) Cellulose nanocrystals from grape pomace: production, properties and cytotoxicity assessment. Carbohydr Polym 192:327336. https://doi.org/10.1016/j.carbpol.2018.03.023

Coma V (2008) Bioactive packaging technologies for extended shelf life of meat-based products. Meat Sci 78:90-103. https://doi.org/10.1016/j.meatsci.2007.07.035

Csiszár E, Nagy S (2017) A comparative study on cellulose nanocrystals extracted from bleached cotton and flax and used for casting films with glycerol and sorbitol plasticisers. Carbohydr Polym 174:740-749. https://doi.org/10. 1016/j.carbpol.2017.06.103

Deepa B, Abraham E, Pothan L et al (2016) Biodegradable nanocomposite films based on sodium alginate and cellulose nanofibrils. Materials (Basel) 9:50. https://doi.org/10. 3390/ma9010050

Duarte EB, das Chagas BS, Andrade FK et al (2015) Production of hydroxyapatite-bacterial cellulose nanocomposites from agroindustrial wastes. Cellulose 22:3177-3187. https://doi.org/10.1007/s10570-015-0734-8

Farhan A, Hani NM (2017) Characterization of edible packaging films based on semi-refined kappa-carrageenan plasticized with glycerol and sorbitol. Food Hydrocoll 64:48-58. https://doi.org/10.1016/j.foodhyd.2016.10.034

Ferreira CO, Nunes CA, Delgadillo I, Silva JAL (2009) Characterization of chitosan-whey protein films at acid $\mathrm{pH}$. Food Res Int 42:807-813. https://doi.org/10.1016/j. foodres.2009.03.005

Fukuzumi H, Saito T, Iwata T et al (2009) Transparent and high gas barrier films of cellulose nanofibers prepared by TEMPO-mediated oxidation. Biomacromol 10:162-165. https://doi.org/10.1021/bm801065u

Fukuzumi H, Saito T, Okita Y, Isogai A (2010) Thermal stabilization of TEMPO-oxidized cellulose. Polym Degrad Stab 95:1502-1508. https://doi.org/10.1016/j.polymdegradstab. 2010.06.015

Gao C, Yan T, Du J et al (2014) Introduction of broad spectrum antibacterial properties to bacterial cellulose nanofibers via immobilising $\varepsilon$-polylysine nanocoatings. Food Hydrocoll 36:204-211. https://doi.org/10.1016/j.foodhyd.2013.09. 015 
Gea S, Reynolds CT, Roohpour N et al (2011) Investigation into the structural, morphological, mechanical and thermal behaviour of bacterial cellulose after a two-step purification process. Bioresour Technol 102:9105-9110. https:// doi.org/10.1016/j.biortech.2011.04.077

Genskowsky E, Puente L, Erez-Alvarez JP et al (2015) Assessment of antibacterial and antioxidant properties of chitosan edible films incorporated with maqui berry (Aristotelia chilensis). LWT-Food Sci Technol 64:1057-1062. https://doi.org/10.1016/j.lwt.2015.07.026

Gómez SA, Marcilla A, Beltran M et al (2012) Study of the oxidative pyrolysis of tobacco-sorbitol-saccharose mixtures in the presence of MCM-41. Thermochim Acta 530:87-94. https://doi.org/10.1016/J.TCA.2011.12.008

Gosslau A (2016) Assessment of food toxicology. Food Sci Hum Wellness 5:103-115. https://doi.org/10.1016/j.fshw. 2016.05.003

Han JH, Gennadios A (2005) Edible films and coatings. A review. Innov Food Packag. https://doi.org/10.1016/B978012311632-1/50047-4

Hermansyah H, Carissa R, Anisa F, et al (2013) Preparation of the edible biocomposite film gelatin/bacterial cellulose microcrystal (BCMC): variation of matrix concentration, filler, and sonication time. In: Advanced Materials Research. Trans Tech Publications, pp 287-293. https:// doi.org/10.4028/www.scientific.net/AMR.789.287

Hestrin S, Schramm M (1954) Synthesis of cellulose by Acetobacter xylinum. II. Preparation of freeze-dried cells capable of polymerizing glucose to cellulose. Biochem J 58:345-352. https://doi.org/10.1042/bj0580345

Hoque MS, Benjakul S, Prodpran T (2011) Effects of partial hydrolysis and plasticizer content on the properties of film from cuttlefish (Sepia pharaonis) skin gelatin. Food Hydrocoll 25:82-90. https://doi.org/10.1016/j.foodhyd. 2010.05.008

Isogai A, Saito T, Fukuzumi H (2011) TEMPO-oxidized cellulose nanofibers. Nanoscale 3:71-85. https://doi.org/10. 1039/C0NR00583E

Jahan F, Kumar V, Saxena RK (2017) Distillery effluent as a potential medium for bacterial cellulose production: a biopolymer of great commercial importance. Bioresour Technol 250:922-926. https://doi.org/10.1016/j.biortech. 2017.09.094

Jozala AF, Novaes LCL, Lopes AM et al (2016) Bacterial nanocellulose production and application: a 10-year overview. Appl Microbiol Biotechnol 100:2063-2072. https:// doi.org/10.1007/S00253-015-7243-4

Kargarzh H, Mariano M, Huange J et al (2017) Recent developments on nanocellulose reinforced polymer nanocomposites: a review. Polymer (Guildf) 132:368-393. https:// doi.org/10.1016/j.polymer.2017.09.043

Kjeldahl J (1883) Neue methode zur bestimmung des stickstoffs in organischen Körpern. Zeitschrift für. Anal Chemie 22:366-382. https://doi.org/10.1007/BF01338151

Lavoine N, Desloges I, Dufresne A, Bras J (2012) Microfibrillated cellulose-its barrier properties and applications in cellulosic materials: a review. Carbohydr Polym 90: 735-764. https://doi.org/10.1016/j.carbpol.2012.05.026

Lima HLS, Nascimento ES, Andrade FK et al (2017) Bacterial Cellulose Production by Komagataeibacter hansenii ATCC 23769 Using Sisal Juice—an agroindustry waste.
Braz J Chem Eng 34:671-680. https://doi.org/10.1590/ 0104-6632.20170343s20150514

Lin Q, Zheng Y, Wang G et al (2015a) Protein adsorption behaviors of carboxymethylated bacterial cellulose membranes. Int J Biol Macromol 73:264-269. https://doi.org/ 10.1016/j.ijbiomac.2014.11.011

Lin SB, Chen CC, Chen LC, Chen HH (2015b) The bioactive composite film prepared from bacterial cellulose and modified by hydrolyzed gelatin peptide. J Biomater Appl 29:1428-1438. https://doi.org/10.1177/08853282145 68799

Martínez AO, Chamorro S, Brenes A (2015) Protein hydrolysates from animal processing by-products as a source of bioactive molecules with interest in animal feeding: a review. Food Res Int 73:204-212. https://doi.org/10.1016/ j.foodres.2015.04.005

Mohammadkazemi F, Azin M, Ashori A (2015) Production of bacterial cellulose using different carbon sources and culture media. Carbohydr Polym 117:518-523. https://doi. org/10.1016/j.carbpol.2014.10.008

Montero PGM, Guillén MCG, Caballero MEL, Cánovas GVB (2017) Edible films and coatings: fundamentals and applications. CRC Press, Boca Raton

Moreno O, Atarés L, Chiralt A (2015) Effect of the incorporation of antimicrobial/antioxidant proteins on the properties of potato starch films. Carbohydr Polym 133:353-364. https://doi.org/10.1016/j.carbpol.2015.07.047

Mu C, Guo J, Li X et al (2012) Preparation and properties of dialdehyde carboxymethyl cellulose crosslinked gelatin edible films. Food Hydrocoll 27:22-29. https://doi.org/10. 1016/j.foodhyd.2011.09.005

Nascimento ES, Lima HLS, Araújo Barroso MK et al (2016) Mesquite (Prosopis juliflora (Sw.)) extract is an alternative nutrient source for bacterial cellulose production. J Biobased Mater Bioenergy 10:63-70. https://doi.org/10. 1166/jbmb.2016.1568

Nguyen VT, Gidley MJ, Dykes GA (2008) Potential of a nisincontaining bacterial cellulose film to inhibit Listeria monocytogenes on processed meats. Food Microbiol 25:471-478. https://doi.org/10.1016/j.fm.2008.01.004

Nociari MM, Shalev A, Benias P, Russo C (1998) A novel onestep, highly sensitive fluorometric assay to evaluate cellmediated cytotoxicity. J Immunol Methods 213:157-167. https://doi.org/10.1016/S0022-1759(98)00028-3

Nowak A, Sójka Michałand Klewicka E, Lipińska L et al (2017) Ellagitannins from Rubus idaeus L. exert geno-and cytotoxic effects against human colon adenocarcinoma cell line caco-2. J Agric Food Chem. https://doi.org/10.1021/acs. jafc.6b05387

Nuanmano S, Prodpran T, Benjakul S (2015) Potential use of gelatin hydrolysate as plasticizer in fish myofibrillar protein film. Food Hydrocoll 47:61-68. https://doi.org/10. 1016/j.foodhyd.2015.01.005

Nur Hanani ZA, McNamara J, Roos YH, Kerry JP (2013) Effect of plasticizer content on the functional properties of extruded gelatin-based composite films. Food Hydrocoll 31:264-269. https://doi.org/10.1016/J.FOODHYD.2012. 10.009

Olivas GI, Cánovas GVB (2008) Alginate-calcium films: water vapor permeability and mechanical properties as affected by plasticizer and relative humidity. LWT-Food Sci 
Technol 41:359-366. https://doi.org/10.1016/j.1wt.2007. 02.015

Padrão J, Gonçalves S, Silva JP et al (2016) Bacterial celluloselactoferrin as an antimicrobial edible packaging. Food Hydrocoll 58:126-140. https://doi.org/10.1016/j.foodhyd. 2016.02.019

Pei Y, Yang J, Liu P et al (2013) Fabrication, properties and bioapplications of cellulose/collagen hydrolysate composite films. Carbohydr Polym 92:1752-1760. https://doi. org/10.1016/j.carbpol.2012.11.029

Perez EPJ, de Fátima Ferreira Soares N, dos Reis Coimbra JS et al (2012) Bioactive Peptides: synthesis, Properties, and Applications in the Packaging and Preservation of Food. Compr Rev Food Sci Food Saf 11:187-204. https://doi.org/ 10.1111/j.1541-4337.2011.00179.x

Piñeros HD, Jaramillo CM, Córdoba AL, Goyanes S (2017) Edible cassava starch films carrying rosemary antioxidant extracts for potential use as active food packaging. Food Hydrocoll 63:488-495. https://doi.org/10.1016/j.foodhyd. 2016.09.034

Podshivalov A, Zakharova M, Glazacheva E, Uspenskaya M (2017) Gelatin/potato starch edible biocomposite films: correlation between morphology and physical properties. Carbohydr Polym 157:1162-1172. https://doi.org/10. 1016/j.carbpol.2016.10.079

Rhim JW (2004) Physical and mechanical properties of water resistant sodium alginate films. LWT-Food Sci Technol 37:323-330. https://doi.org/10.1016/j.lwt.2003.09.008

Rodionova G, Saito T, Lenes M et al (2012) Mechanical and oxygen barrier properties of films prepared from fibrillated dispersions of TEMPO-oxidized Norway spruce and $\mathrm{Eu}$ calyptus pulps. Cellulose 19:705-711. https://doi.org/10. 1007/s10570-012-9664-X

Saito T, Nishiyama Y, Putaux JL et al (2006) Homogeneous suspensions of individualized microfibrils from TEMPOcatalyzed oxidation of native cellulose. Biomacromol 7:1687-1691. https://doi.org/10.1021/BM060154S

Saito T, Kimura S, Nishiyama Y, Isogai A (2007) Cellulose nanofibers prepared by TEMPO-mediated oxidation of native cellulose. Biomacromol 8:2485-2491. https://doi. org/10.1021/bm0703970

Salgado PR, Ortiz CM, Musso YS et al (2015) Edible films and coatings containing bioactives. Curr Opin Food Sci 5:86-92. https://doi.org/10.1016/j.cofs.2015.09.004

Samaranayaka AGP, Li CECY (2011) Food-derived peptidic antioxidants: a review of their production, assessment, and potential applications. J Funct Foods 3:229-254. https:// doi.org/10.1016/j.jff.2011.05.006

Sampaio APC, Filho MSMS, Castro ALA, Figueirêdo MCB (2017) Life cycle assessment from early development stages: the case of gelatin extracted from tilapia residues. Int J Life Cycle Assess 22:767-783. https://doi.org/10. 1007/s11367-016-1179-5

Santos TM, Filho MSMS, Caceres CA et al (2014) Fish gelatin films as affected by cellulose whiskers and sonication. Food Hydrocoll 41:113-118. https://doi.org/10.1016/j. foodhyd.2014.04.001

Schmid M, Hinz LV, Wild F, Noller K (2013) Effects of hydrolysed whey proteins on the techno-functional characteristics of whey protein-based films. Materials (Basel) 6:927-940. https://doi.org/10.3390/ma6030927
Segal L, Creely JJ, Martin AE, Conrad CM (1959) An empirical method for estimating the degree of crystallinity of native cellulose using the X-ray diffractometer. Text Res J 29:786-794. https://doi.org/10.1177/0040517559029 01003

Shi Z, Zhang Y, Phillips GO, Yang G (2014) Utilization of bacterial cellulose in food. Food Hydrocoll 35:539-545. https://doi.org/10.1016/j.foodhyd.2013.07.012

Sila A, Bougatef A (2016) Antioxidant peptides from marine byproducts: isolation, identification and application in food systems. A review. J Funct Foods 21:10-26. https://doi. org/10.1016/j.jff.2015.11.007

Silveira MS, Fontes CPML, Guilherme AA et al (2012) Cashew apple juice as substrate for lactic acid production. Food Bioprocess Technol 5:947-953. https://doi.org/10.1007/ s11947-010-0382-9

Soni B, Hassan EB, Schilling MW, Mahmoud B (2016) Transparent bionanocomposite films based on chitosan and TEMPO-oxidized cellulose nanofibers with enhanced mechanical and barrier properties. Carbohydr Polym 151:779-789. https://doi.org/10.1016/j.carbpol.2016.06. 022

Sun J, Furio L, Mecheri R et al (2015) Pancreatic $\beta$-cells limit autoimmune diabetes via an immunoregulatory antimicrobial peptide expressed under the influence of the gut microbiota. Immunity 43:304-317. https://doi.org/10. 1016/j.immuni.2015.07.013

Syverud K, Stenius P (2009) Strength and barrier properties of MFC films. Cellulose 16:75-85. https://doi.org/10.1007/ s10570-008-9244-2

Thomazine M, Carvalho RA, Sobral PJA (2006) Physical properties of gelatin films plasticized by blends of glycerol and sorbitol. J Food Sci 70:E172-E176. https://doi.org/10. 1111/j.1365-2621.2005.tb07132.x

Tongnuanchan P, Benjakul S, Prodpran T (2012) Properties and antioxidant activity of fish skin gelatin film incorporated with citrus essential oils. Food Chem 134:1571-1579. https://doi.org/10.1016/j.foodchem.2012.03.094

Tongnuanchan P, Benjakul S, Prodpran T, Nilsuwan K (2015) Emulsion film based on fish skin gelatin and palm oil: physical, structural and thermal properties. Food Hydrocoll 48:248-259. https://doi.org/10.1016/j.foodhyd.2015.02. 025

Tsalagkas D, Lagaňa R, Poljanšek I et al (2016) Fabrication of bacterial cellulose thin films self-assembled from sonochemically prepared nanofibrils and its characterization. Ultrason Sonochem 28:136-143. https://doi.org/10.1016/j. ultsonch.2015.07.010

Ullah H, Santos HA, Khan T (2016) Applications of bacterial cellulose in food, cosmetics and drug delivery. Cellulose 23:2291-2314. https://doi.org/10.1007/s10570-016-0986$\mathrm{y}$

Wu CN, Cheng KC (2017) Strong, thermal-stable, flexible, and transparent films by self-assembled TEMPO-oxidized bacterial cellulose nanofibers. Cellulose 24:269-283. https://doi.org/10.1007/s10570-016-1114-8

Xu M, McCanna DJ, Sivak JG (2015) Use of the viability reagent PrestoBlue in comparison with alamarBlue and MTT to assess the viability of human corneal epithelial cells. J Pharmacol Toxicol Methods 71:1-7. https://doi. org/10.1016/j.vascn.2014.11.003 
Yamada Y, Yukphan P, Vu HTL et al (2012) Subdivision of the genus Gluconacetobacter Yamada, Hoshino and Ishikawa 1998: the proposal of Komagatabacter gen. nov., for strains accommodated to the Gluconacetobacter xylinus group in the $\alpha$-Proteobacteria. Ann Microbiol 62:849-859. https://doi.org/10.1007/s13213-011-0288-4

Yang JII, Liang WSS, Chow CJJ, Siebert KJ (2009) Process for the production of tilapia retorted skin gelatin hydrolysates with optimized antioxidative properties. Process Biochem 44:1152-1157. https://doi.org/10.1016/j.procbio.2009.06. 013
Yunos MZB, Rahman WAWA (2011) Effect of glycerol on performance rice straw/starch based polymer. J Appl Sci 11:2456-2459. https://doi.org/10.3923/jas.2011.2456. 2459

Zhang SB (2016) In vitro antithrombotic activities of peanut protein hydrolysates. Food Chem 202:1-8. https://doi.org/ 10.1016/j.foodchem.2016.01.108

Zhijiang C, Guang Y (2010) Bacterial cellulose/collagen composite: characterization and first evaluation of cytocompatibility. J Appl Polym Sci 120:2938-2944. https://doi. org/10.1002/app.33318 